\title{
Strategic Entrepreneurship in Russia during Economic Crisis
}

\author{
Galina Shirokova \\ Professor a; Research Fellow ${ }^{\text {b }}$, shirokova@gsom.pu.ru
}

Liudmila Ivvonen

Doctoral Student ${ }^{\text {a }}$, ivvonen@gmail.com

Elena Gafforova

Professor ${ }^{\mathrm{b}}$, gafforova.eb@dvfu.ru

a St. Petersburg University, Graduate School of Management, 3 Volkhovsky ln, St. Petersburg 199004, Russian Federation

${ }^{\mathrm{b}}$ Far Eastern Federal University, School of Economics and Management, 8 Sukhanova str.,

Vladivostok 690091, Russian Federation

\begin{abstract}
his paper aims to explore the relationship between different components of strategic entrepreneurship (particularly, entrepreneurial mindset, innovation, managing resources strategically, and competitive advantage) and SME performance during the economic crisis. To test the theoretical model, we utilize data collected through a survey of Russian SMEs during the period of economic crisis and subsequent stagnation in 2015-2016. The findings

suggest that the entrepreneurial component of strategic entrepreneurship is positively related to SME performance during the economic crisis; moreover, a significant negative link was found between SME performance of firms outside the Central Federal Region and an interaction term of Entrepreneurial Component and Competitive Advantage that suggests the need to choose only one type of action and not to perform both simultaneously.
\end{abstract}

Keywords: strategic entrepreneurship; innovation; entrepreneurial mindset; managing resources strategically; competitive advantage; small and medium enterprise; performance; economic crisis; Russia.
Citation: Shirokova G., Ivvonen L., Gafforova E. (2019) Strategic Entrepreneurship in Russia during Economic Crisis. Foresight and STI Governance, vol. 13, no 3, pp. 62-76. DOI: 10.17323/2500-2597.2019.3.62.76 
$\mathrm{T}$ he negative impact of economic crises on businesses, especially small and medium ones, manifests itself in reduced growth rates and an increased number of bankruptcies. The introduction of economic and political sanctions against Russia in mid-March 2014 resulted in the reduction of trade between Russian companies and international partners and created the need to substitute imports with similar domestic products. The crisis has led to the simultaneous decline of a whole range of macroeconomic indicators affecting various industries, regions, and companies in different ways. In particular, according to Rosstat, ${ }^{1}$ the GDP growth rate declined by 3.7 percentage points in 2015 and subsequently stagnated at $0.3 \%$ in 2016 . The national currency depreciated by almost 50\%, against the background of halving oil prices. Inflation soared to $12.9 \%$ in 2015 (5.38\% in 2016) and unemployment rose to $5.6 \%$ in 2015 (5.4\% in 2016), which led to a major decline in investments and people's income. The crisis has significantly changed the needs for organizational competencies, and the overall competitive environment.

Managing small and medium enterprises (SMEs) becomes a serious challenge during crisis periods, since companies doing business on a much smaller scale than large firms face problems with attracting financial and human resources [Carreira, Silva, 2010; Schmitt et al., 2010]. SMEs' share in Russian GDP is just $21.9 \%$ while the average figure for Europe ranges between $50-60 \%{ }^{2}$. However, even under stable conditions, Russian SMEs tend to experience a serious shortage of the resources they need to accomplish their objectives [Chepurenko, 2015], so the recession has only aggravated the situation further.

Finding new approaches to managing companies in a turbulent economic situation therefore becomes critically important. A possible option is advancing strategic entrepreneurship (SE) by "integrating the entrepreneurial (identifying business opportunities) and strategic (identifying competitive advantages) perspectives to plan and implement value creation actions" [Hitt et al., 2001, p. 481]. SE implies combining advantage-seeking and opportunity-seeking [Ireland et al., 2003]. The issue of coordinating entrepreneurial actions (which create new opportunities) with strategic actions aimed at strengthening competitive advantages at the individual firm level has been little studied [Hitt et al., 2007].

The goal of this study is to identify and assess the connections between various SE components (such as entrepreneurial mindset, innovation, strategic management of resources, and competitive advantages) and the activities of Russian SMEs during economic crises. A configurational approach [Wiklund, Shepherd, 2005] was applied for this purpose, which helps one understand which combination of the above components increases SE benefits for a company. The objectives of the study included the following: 1) analyze the conceptual basics of SE and approaches to their operationalization; 2) propose and theoretically substantiate hypotheses on the nature of the relationship between various SE components and companies' performance during economic crises; 3 ) describe the methods of the study; 4) empirically test the hypotheses; 5) describe and analyze the obtained results. Data collected through a survey of SMEs conducted between September 2015 and February 2016 was used to empirically test the suggested hypotheses. A total of 614 firms operating in various industries and various Russian Federal Districts were included in the final sample.

\section{The Theoretical Model and Hypotheses of the Study}

\section{The Role of SE in Company Operations}

The SE concept originates in both economics [Knight, 1921; Schumpeter, 1942] and management theory [Hitt et al., 2001]. A number of studies were devoted to analyzing the relationship between strategic management and entrepreneurship. It was mentioned in the special issue of the Strategic Management Journal for the first time in 2001, where this concept was defined as a scientific theory at the junction of entrepreneurship and strategic management [Hitt et al., 2001; Ivvonen, Shirokova, 2016]. The entrepreneurial aspect of SE is aimed at identifying business opportunities and the potential for implementing them, while the strategic one is identifying and making use of the opportunities most likely to create sustainable competitive advantages [Hitt et al., 2001]. The basic SE-related studies, and recent bibliometric research show that SE fosters mutual support and interdependence between entrepreneurship and strategic management [Hitt et al., 2002]. This includes studying the sources of opportunities, the processes of identifying, assessing, and making use of opportunities, and the circle of people who identify, assess, and make use of them [Shane, Venkataraman, 2000, p. 218].

At the initial stages of venture creation and launch, entrepreneurs often have to do more with less and use what abilities and resources they have at their disposal with a minimum of capital and a maximum of ingenuity and improvisation [Harrison et al., 2004; Miner et al., 2001].

Strategy is often likened to a process of planning that places the emphasis on improved decision-making brought about by managing resources within a framework of structures, systems and processes. Strategy provides the main advantage that differentiates firms

\footnotetext{
For the details see: www.gks.ru, accessed 18.04.2019.

${ }^{2}$ For the details see: http://ec.europa.eu/eurostat, accessed 18.04.2019.
} 
and gives them organizational superiority [Darling et al., 2007]. It creates a context where firms can make use of the identified opportunities thus contributing to enhanced specialization and obtaining a competitive advantage. However,ntrepreneurial firms risk focusing excessively on opportunity recognition and risktaking activities; finding new opportunities frequently involves serious riskslacking a balanced strategic focus can undermine the benefits and value entrepreneurial initiatives might generate. Excessive formalization of companies' organizational activities is also fraught with undesirable consequences. This limits the scope for rapid adaptation to changes and sensitivity to revolutionary ideas [DeSimone, Hatsopoulos, 1995], that is, it ultimately hinders one from reaping the full benefits of entrepreneurial activities. Balancing entrepreneurship and strategic management then can help firms avoid the trap of excessive risk-taking activities, while preventing inertia caused by iteratively adding to present advantages.

Earlier studies have also noted the interconnections between strategic management and entrepreneurship. Covin and Slevin (1989), following Miller's (1983) conception of an entrepreneurial firm, define strategic posture as a firm's competitive orientation on a spectrum from conservative to entrepreneurial. For example, the "entrepreneurial firm" theory [Miller, 1983] defines strategic position as a competitive orientation ranging from conservative to entrepreneurial [Covin, Slevin, 1989]. Lumpkin and Dess [Lumpkin, Dess, 1996] subsequently developed the construct of entrepreneurial orientation. The concept of entrepreneurial orientation describes companies' behaviour in terms of their innovation, proactivity, and willingness to take risks. More recent studies suggested the term "entrepreneurial strategy" [Meyer, Heppard, 2000], while strategic management was seen as providing the context for entrepreneurial activities [Ireland et al., 2001]. An analysis of the relationship between the intensity of entrepreneurship and five specific strategic management techniques revealed that the former was positively affected by focusing on the searching, flexibility, and planning locus, combined with strategic control [Barringer, Bluedorn, 1999]. Therefore the relationship between strategic management and entrepreneurial activity has emerged in an interrelated way over many years, but has only now been crystallised into a construct of SE.

Strategic management theory, epitomised by the RBV, emphasises the creation of a unique resource position for the firm to create advantages that allow it to compete effectively into the long term (Barney, 1991; Wernerfelt, 198?). The first empirical studies which have directly analysed the correlation between SE and companies' performance were published in 2009. Only a relatively small number of such studies exist (Table 1), which can be explained, among other things, by the problems with operationalizing the SE concept. Most of the studies are quantitative, based on SME statistics from various countries. The relationship between SE and companies' productivity is often seen through the prism of external and internal conditions, and specific features of their activities. In particular, studies focusing on the role of the external environment consider factors such as national culture $[Y u, H u, 2015]$ and the level of the country's institutional development [Awang et al., 2015; Bjørnskov, Foss, 2013; Obeng et al., 2014; Shirokova et al., 2013]. For example, the cultural traits of Malaysian entrepreneurs, in particular, their willingness to take risks, positively affect the successful performance of the country's SMEs [Yu, Hu, 2015]. The results of a Ghanaian study [Obeng et al., 2014] confirm that SE contributes to businesses' productivity in developing economies. Data on Russian SMEs [Shirokova et al., 2013] does not show a statistically significant correlation of this kind, but still confirms that certain components of SE do play a positive role. Interactions with other firms over the course of joint innovation activities was also considered among the relevant external factors [Löfgren, 2014; Meuleman et al., 2009].

A few studies were specifically focused on the role internal factors play in the relationship between SE and business productivity [Sirén et al., 2012; Steffens et al., 2009]. It was established that strategic training directly affects this relationship [Sirén et al., 2012]. Knowledge spillovers, that is, its unintended dissemination caused by the specific qualities of this economic benefit and resource, promotes the development of SE (companies' innovation activity) and contributes to the even more efficient use of their current advantages, which leads to improved performance indicators [Kotha, 2010].

Also, the correlation between SE and companies' performance was analyzed in various sectors of the economy [Luke et al., 2011; Patzelt, Shepherd, 2009]. A positive correlation was discovered in the public [Luke et al., 2011], education [Patzelt, Shepherd, 2009], and tourism [Carlbäck, 2012] sectors. The main results of the relevant studies are summarized in Table 1.

Thus, SE implies simultaneously taking entrepreneurial and strategic actions to create value. Kyrgidou and Petridou [Kyrgidou, Petridou, 2011] include an entrepreneurial mindset and innovation in the entrepreneurial component of $\mathrm{SE}$ and the strategic management of resources and competitive advantage in the strategic one. Entrepreneurial mindset suggests focusing on creativity and modernization, the conscious effort to find, identify, and implement new opportunities [Benedict, Venter, 2010; Ireland et al., 2003]. Innovation allows companies use the identified opportunities in radically new, revolutionary ways, thus significantly changing the very competitive environment in the industry [Danneels, 2002; Kumaraswamy et al., 2018]. The above means that we use the term "innovation" broadly, referring to product and organizational innovations alike. The strategic management of resources means structuring, grouping, and reallocating the resources available to the company [Kyrgidou, Petridou, 
Table 1. Empirical Studies of Correlation between SE and Company Performance

\begin{tabular}{|c|c|c|c|c|}
\hline Authors & SE components & Method & Context & Main results \\
\hline $\begin{array}{l}\text { [Meuleman et al., } \\
\text { 2009] }\end{array}$ & $\begin{array}{l}\text { Identifying opportunities for } \\
\text { growth to create and maintain } \\
\text { competitive advantages. }\end{array}$ & Survey & 238 companies, UK & $\begin{array}{l}\text { The more actively a company works with } \\
\text { private investors, the more rapidly it grows. }\end{array}$ \\
\hline [Steffens et al., 2009] & $\begin{array}{l}\text { Finding new areas, advancing } \\
\text { existing ones. }\end{array}$ & Survey & $\begin{array}{l}2,662 \text { companies, } \\
\text { Australia }\end{array}$ & $\begin{array}{l}\text { Though young companies do find growth } \\
\text { opportunities, it is hard for them to identify } \\
\text { and make full use of the ones most relevant } \\
\text { for their businesses. }\end{array}$ \\
\hline $\begin{array}{l}\text { [Patzelt, Shepherd, } \\
\text { 2009] }\end{array}$ & $\begin{array}{l}\text { Identifying and making use of } \\
\text { opportunities by developing } \\
\text { new products and services, } \\
\text { taking strategic action to ac- } \\
\text { complish development objec- } \\
\text { tives. }\end{array}$ & Survey & $\begin{array}{l}98 \text { academic entre- } \\
\text { preneurs, Germany }\end{array}$ & $\begin{array}{l}\text { Combining internal business policies, } \\
\text { among other things to secure financial } \\
\text { support, improves expected SE results at } \\
\text { universities. }\end{array}$ \\
\hline [Kotha, 2010] & $\begin{array}{l}\text { Identifying opportunities and } \\
\text { advantages. }\end{array}$ & Case study & $\begin{array}{l}\text { Four aviation compa- } \\
\text { nies, US }\end{array}$ & $\begin{array}{l}\text { Knowledge exchanges increase the aware- } \\
\text { ness of new opportunities, the potential to } \\
\text { develop competitive advantages, and to ul- } \\
\text { timately improve company performance. }\end{array}$ \\
\hline [Luke et al., 2011] & $\begin{array}{l}\text { Combining innovations, find- } \\
\text { ing opportunities for growth. }\end{array}$ & Case study & $\begin{array}{l}12 \text { state-owned com- } \\
\text { panies, New Zealand }\end{array}$ & $\begin{array}{l}\text { Advancing SE in state-owned companies } \\
\text { increases their profits. }\end{array}$ \\
\hline [Sirén et al., 2012] & $\begin{array}{l}\text { Finding new areas, advancing } \\
\text { existing ones. }\end{array}$ & Survey & $\begin{array}{l}206 \text { IT companies, } \\
\text { Finland }\end{array}$ & $\begin{array}{l}\text { Making use of existing opportunities and } \\
\text { finding new ones does not directly affect } \\
\text { companies' performance, strategic training } \\
\text { fully promotes the above correlation. }\end{array}$ \\
\hline [Carlbäck, 2012] & $\begin{array}{l}\text { Finding new areas, advancing } \\
\text { the existing ones. }\end{array}$ & Case study & $\begin{array}{l}12 \text { private hotels, } \\
\text { Sweden }\end{array}$ & $\begin{array}{l}\text { The companies value their independence, } \\
\text { but at the same time it does not allow the } \\
\text { hotels to apply advanced technological so- } \\
\text { lutions and loyalty schemes. Membership } \\
\text { in major hotel chains is a way to overcome } \\
\text { these limitations, i.e., it increases the hotels' } \\
\text { efficiency and revenues. }\end{array}$ \\
\hline $\begin{array}{l}\text { [Bjørnskov, Foss, } \\
2013]\end{array}$ & $\begin{array}{l}\text { R\&D, process, management, } \\
\text { and organizational innova- } \\
\text { tions, mobilizing and coordi- } \\
\text { nating resources. }\end{array}$ & Survey & $\begin{array}{l}140 \text { entrepreneurs, } \\
\text { OECD member states }\end{array}$ & $\begin{array}{l}\text { SE positively affects overall productivity. } \\
\text { Institutions weaken this correlation since } \\
\text { they increase uncertainty and transaction } \\
\text { costs entrepreneurs face. }\end{array}$ \\
\hline $\begin{array}{l}\text { [Shirokova et al. } \\
\text { 2013] }\end{array}$ & $\begin{array}{l}\text { Identifying new opportunities } \\
\text { (entrepreneurial focus and } \\
\text { culture), making use of exist- } \\
\text { ing ones (investing in internal } \\
\text { resources and knowledge- } \\
\text { based assets, organizational } \\
\text { changes, training). }\end{array}$ & Survey & 500 SMEs, Russia & $\begin{array}{l}\text { Identifying new opportunities and making } \\
\text { use of existing ones positively affects com- } \\
\text { panies' performance. The latter's correlation } \\
\text { with SE turned out to be insignificant. }\end{array}$ \\
\hline [Löfgren, 2014] & $\begin{array}{l}\text { Making use of existing com- } \\
\text { petitive advantages, identify- } \\
\text { ing potential opportunities. }\end{array}$ & Survey & 188 SMEs, Sweden & $\begin{array}{l}\text { Joint innovation promotes and strengthens, } \\
\text { the correlation between SE and companies' } \\
\text { international growth. }\end{array}$ \\
\hline [Obeng et al., 2014] & $\begin{array}{l}\text { Identifying and making use of } \\
\text { value creation opportunities. }\end{array}$ & Survey & $\begin{array}{l}441 \text { entrepreneurs, } \\
\text { Ghana }\end{array}$ & $\begin{array}{l}\text { There is a positive correlation between SE } \\
\text { and small companies' growth. }\end{array}$ \\
\hline$[Y u, H u, 2015]$ & $\begin{array}{l}\text { Finding new areas, advancing } \\
\text { existing ones. }\end{array}$ & Case study & $\begin{array}{l}\text { One hospitality SME } \\
\text { (HoReCa), Taiwan }\end{array}$ & $\begin{array}{l}\text { Cognitive entrepreneurial processes (deci- } \\
\text { sion-making, opportunity assessment) help } \\
\text { identify opportunities and promote growth. }\end{array}$ \\
\hline [Sun, 2015] & $\begin{array}{l}\text { Sensitivity to new opportuni- } \\
\text { ties, finding resources, strate- } \\
\text { gic training. }\end{array}$ & Case study & $\begin{array}{l}\text { Four railway com- } \\
\text { panies and affiliates, } \\
\text { China }\end{array}$ & $\begin{array}{l}\text { The effect of "entrepreneurial state" on the } \\
\text { emergence of SE is manifested in the cre- } \\
\text { ation of technological innovations (as op- } \\
\text { posed to imitating them), which improves } \\
\text { businesses' performance. }\end{array}$ \\
\hline [Awang et al., 2015] & $\begin{array}{l}\text { Entrepreneurial mindset, } \\
\text { combining the search for new } \\
\text { opportunities with the use } \\
\text { of existing ones, ongoing in- } \\
\text { novation. }\end{array}$ & Survey & 46 SMEs, Malaysia & $\begin{array}{l}\text { Malaysian entrepreneurs' traits, such as risk } \\
\text { tolerance, striving for success, the ability } \\
\text { to efficiently deal with problems, and the } \\
\text { willingness to learn positively affect the } \\
\text { correlation between SE and companies' } \\
\text { performance. }\end{array}$ \\
\hline [Kantur, 2016] & $\begin{array}{l}\text { Sustainable regeneration, } \\
\text { organizational rejuvenation, } \\
\text { strategic modernization, rede- } \\
\text { fining domains. }\end{array}$ & Survey & $\begin{array}{l}114 \text { production (au- } \\
\text { tomotive and food } \\
\text { industry) and service } \\
\text { companies (telecom- } \\
\text { munications, bank- } \\
\text { ing), Turkey }\end{array}$ & $\begin{array}{l}\text { SE is positively connected with company } \\
\text { performance. }\end{array}$ \\
\hline
\end{tabular}


2011]. Finally, competitive advantages allow companies to secure a market position protected from action by the competition by using their existing advantages in combination with newly found opportunities [Ireland et al., 2003; Maury, 2018].

\section{The Entrepreneurial Component of SE and SMEs' Performance during Economic Crises}

Most of the empirical studies on SE were based on data for developed (i.e. sustainable) or emerging markets [Boone et al., 2013; Dhliwayo, 2014; Ireland, Webb, 2007; Ketchen et al., 2007; Löfgren, 2014; Meuleman et al., 2009; Mihalache et al., 2014], which puts into doubt this concept's applicability to developing markets during economic crises [Knudsen, Lien, 2016].

A crisis is frequently defined as a situation of an uncertain external environment which poses a serious threat to the organization's survival [Kunc, Bhandari, 2011; Pearson, Clair, 1998], while the reasons for and consequences of this situation remain unpredictable [Dutton, 1986]. The time for finding an adequate response is limited and the results of the decisions made may turn out to be favorable or unfavorable [Grewal, Tansuhaj, 2001; Marcus, Goodman, 1991]. Economic crises stand out among various others such as those caused by political developments, anthropogenic disasters, or mismanagement. They are manifested in the acutely negative dynamics of a whole range of economic in dicators, from gross domestic product, inflation, and unemployment to financial market indices, currency rates, and so on. Economic crises affect various industries, regions, and companies differently [Connaughton, Madsen, 2009]. They radically change the requirements for organizational competencies and the very competitive environment [Knudsen, Lien, 2016]. Along with a sharp decline in demand and the growth rate [Pearson, Clair, 1998], companies frequently encounter risks and uncertainty in their strategic planning, which is fraught with reduced market share and profit margins. Successfully managing a company during a crisis period, which is a serious challenge for any company [Schmitt et al., 2010], requires particular skills from SMEs whose situation is further aggravated by the "liability of smallness" effect [Aldrich, Auster, 1986] which makes it harder for such firms to survive, and increases the likelihood of their bankruptcy [Aldrich, Auster, 1986; Mellahi, Wilkinson, 2004]. In particular, they face problems with attracting financial capital [Carreira, Silva, 2010], have to compete for workers with large companies, and face high administrative costs [Aldrich, Auster, 1986]. Plus, SMEs are more dependent on external resources [Baum, Oliver, 1996] and become hostages to the modest scale of their operations [Audretsch, Mahmood, 1994].

However, crises also open potential opportunities for SMEs [Beliaeva et al., 2018; Soininen et al., 2012]. During crisis periods small companies may find it easier to operate, offer new products and services due to their inherent maneuvrability and find they can rapidly react to the emergence of new opportunities [AlonsoAlmeida et al., 2015; Hodorogel, 2009; Laskovaia et al., 2019]. Such firms have the flexibility that allows them to quickly reallocate resources, restructure processes, adjust prices, and adapt products to the crisis conditions [Reid, 2007]. They are more willing to take risks and invest to improve their performance since they are aware that all their current achievements are temporary by default. A survey of US software companies conducted during the crisis of 2001-2003 revealed that in such a situation, young small firms chose a new product development strategy over cost-cutting much more often than larger companies did [Latham, 2009]. A study of small companies' behavior in the Italian Emilia-Romagna region showed that during a period of economic recession they tended to be more innovative than larger players [Antonioli et al., 2010]. Those who focused on developing new products and finding new markets in most cases dealt with crises better than others. A survey of 172 Turkish companies [Köksal, Özgül, 2007] yielded similar results: firms focused on product development to secure new market niches tended to be more productive during periods of recession than their competitors. All this allows one to suggest the first hypothesis:

Hypothesis 1: During an economic crisis, a positive correlation is observed between the entrepreneurial component of SE and SME performance.

\section{The Strategic Component of SE and SME Performance during Economic Crises}

The strategic component of SE is focused on making use of competitive advantages and on the strategic management of available resources [Kyrgidou, Petridou, 2011]. Effective strategic action is seen as the key to making the company competitive [Makadok, Coff, 2002; Luke et al., 2011], while maintaining competitiveness (and the profit margins) requires the efficient management of corporate resources. In a situation of severe limitations SMEs have to improvise to find new or allocate available resources, which makes them less transparent to potential competitors [De Oliveira Teixeira, Werther, 2013]. The consequences of economic crises that threaten companies at the same time increase their motivation to take strategic action, which smooths over the fluctuations of companies' revenue by optimizing their operations and helping them to better adapt to the current situation [March, 1991; Uotila et al., 2009].

Economic crises primarily manifest themselves in the significantly reduced availability of resources for companies since customers cut their spending, creditors cut lending, while pressure from the competition increases [Pearce, Michael, 2006]. In such circumstances, many players focus on strategic action which provides short-term visible results [Schmitt et al., 2010] and secures more predictable and more immediate profits [He, Wong, 2004; Levinthal, March, 1993; March, 1991]. Focusing on the strategic management of resources 
and making use of competitive advantages increases SMEs' chances of maintaining profit margins despite the falling sales and financial instability. Though most companies see economic crises as a threat, some, especially those in the SME group, use them to take advantage of newly emerging opportunities and expand their operations [Beliaeva et al., 2018; Kunc, Bhandari, 2011]. They see turbulence as a source of new business opportunities, including maintaining their competitiveness or identifying new sources of competitive advantages, for example, by procuring their competitors or suppliers [Wan, Yiu, 2009]. This allows us to suggest a second hypothesis:

Hypothesis 2: During an economic crisis a positive correlation exists between the strategic component of $S E$ and SME performance.

\section{The Synergy between the Entrepreneurial and Strategic Components of SE}

Entrepreneurship involves applying new solutions on the market [Zahra et al., 2006]. Strategy, in its turn, amounts to applying structured, calculated approaches to efficiently using resources in order to obtain competitive advantages and create value [Eisenhardt, Martin, 2000]. Entrepreneurship and strategy are conceptually inseparable: as two sides of the same coin, they are complementary in nature [Luke et al., 2011] and combining them creates synergy [Dhliwayo, 2014]. Placing one's chips on just one behavior type turns out to be less productive than simultaneously taking entrepreneurial and strategic action, which helps SMEs deal with a wider range of unforeseen circumstances emerging during economic crises [Dhliwayo, 2014; Smolka et al., 2016].

Previous empirical studies confirm that a positive correlation exists between simultaneously taking entrepreneurial and strategic action and companies' performance [Gibson, Birkinshaw, 2004; He, Wong, 2004; Lubatkin et al., 2006]. Some researchers believe that during a recession the need for combining these approaches only increases [Jansen et al., 2006]. To promote further growth, companies should combine taking steps to increase productivity with creating innovations. During economic crises such "ambidexterity" frequently ensures the business's survival [Raisch et al., 2009]. Combining entrepreneurial and strategic behavior positively affects performance in a volatile environment [McGrath, 2001; Siggelkow, Levinthal, 2003]. Companies capable of simultaneously increasing productivity and finding new business opportunities have a better chance of improving their positions during a recession. Both these strategies help one remain flexible in an uncertain situation [Volberda, 1996], alleviate the consequences of economic shocks to businesses, maintain development potential, and market transparency. This allows us to suggest the third hypothesis:

Hypothesis 3: During an economic crisis, the combination of the entrepreneurial and strategic components of $S E$ positively affects SME performance.
The theoretical model of the study is presented in Figure 1.

\section{Methodology of the Study}

\section{Context of the Study and the Sample Description}

To test the hypotheses of the study, we have used data collected through a survey of representatives of Russian SMEs conducted during the economic crisis and political sanctions between September 2015 and February 2016. The survey was conducted by the Entrepreneurship Centre of the St. Petersburg State University Graduate School of Management jointly with the School of Economics and Management of the Far-Eastern Federal University.

The sample of private Russian companies was randomly generated using main state registration numbers (MSRN). The MSRN codes were subsequently uploaded into the Professional Market and Company Analysis System (SPARK-Interfax) to verify their accuracy, collect information about the companies and their key financial indicators, and filter out data not meeting the selection criteria adopted for the study. The final sample included 10,359 firms.

A standardized questionnaire was used to conduct the survey. The methodology combined online survey tools and telephone interviews. A total of 656 returned questionnaires out of 2,583 sent out mean that the effective response rate was $25.2 \%$. After clearing the data of missing values, 614 Russian companies were included in the final sample.

The predominant share of the companies in the sample were classified as small businesses (less than 100 employees). Most of them specialize in wholesale trade $(21.82 \%)$, services $(21.50 \%)$, and retail $(17.43 \%)$. Somewhat fewer companies operate in the manufacturing (16.94\%) and construction (11.56\%) industries. The companies in the sample are distributed throughout the country, but mainly concentrated in

Figure 1. Theoretical Model of the Study

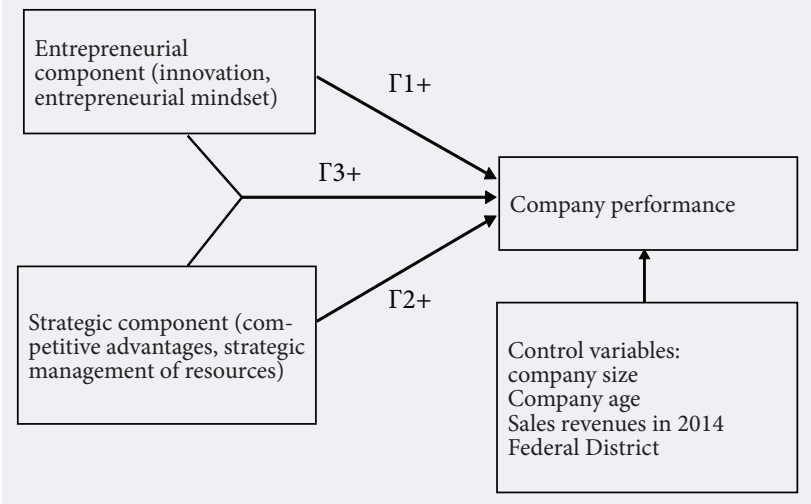

Source: compiled by the authors. 
Table 3. Descriptive Statistics

\begin{tabular}{|c|c|c|c|c|}
\hline Variable & Average & $\begin{array}{l}\text { Standard } \\
\text { deviation }\end{array}$ & Minimum & Maximum \\
\hline \multicolumn{5}{|c|}{ Dependent variable } \\
\hline Performance $\left(\mathrm{Y}_{\mathrm{i}}\right)$ & 4.350 & 1.017 & 1 & 7 \\
\hline \multicolumn{5}{|c|}{ Independent variables } \\
\hline Entrepreneurial component $\left(\mathrm{ENT}_{\mathrm{i}}\right)$ & 4.653 & 1.414 & 1 & 7 \\
\hline Strategic component $\left(\mathrm{STR}_{\mathrm{i}}\right)$ & 4.692 & 1.181 & 1 & 7 \\
\hline Entrepreneurial mindset $\left(\mathrm{EM}_{\mathrm{i}}\right)$ & 4.377 & 1.533 & 1 & 7 \\
\hline Innovation $\left(I_{i}\right)$ & 4.929 & 1.528 & 1 & 7 \\
\hline Strategic management of resources $\left(\mathrm{RS}_{\mathrm{i}}\right)$ & 4.200 & 1.511 & 1 & 7 \\
\hline Competitive advantage $\left(\mathrm{CA}_{\mathrm{i}}\right)$ & 5.185 & 1.358 & 1 & 7 \\
\hline \multicolumn{5}{|c|}{ Control variables } \\
\hline Company size (number of full-time employees) $\left(\mathrm{SIZE}_{\mathrm{i}}\right.$ ) & 41 & 62 & 3 & 426 \\
\hline Company age, years $\left(\mathrm{AGE}_{\mathrm{i}}\right)$ & 12.653 & 14.469 & 0 & 122 \\
\hline Sales revenue in 2014 , thousand roubles $\left(\mathrm{REV}_{\mathrm{i}}\right)$ & 9.093 & 1.973 & 1.791 & 16.714 \\
\hline High-technology industries and services (IND) & - & - & 0 & 1 \\
\hline \multicolumn{5}{|c|}{ Federal Districts } \\
\hline Central Federal District $\left(\mathrm{CFO}_{\mathrm{i}}\right)$ & - & - & 0 & 1 \\
\hline Southern Federal District $\left(\mathrm{SFO}_{\mathrm{i}}\right)$ & - & - & 0 & 1 \\
\hline North-Western Federal District $\left(\mathrm{NFO}_{\mathrm{i}}\right)$ & - & - & 0 & 1 \\
\hline Far-Eastern Federal District $\left(\mathrm{FFO}_{\mathrm{i}}\right)$ & - & - & 0 & 1 \\
\hline Siberian Federal District $\left(\mathrm{SibFO}_{\mathrm{i}}\right)$ & - & - & 0 & 1 \\
\hline Urals Federal District $\left(\mathrm{UFO}_{\mathrm{i}}\right)$ & - & - & 0 & 1 \\
\hline Volga Federal District (VFO & - & - & 0 & 1 \\
\hline North Caucasus Federal District $\left(\mathrm{NCFO}_{\mathrm{i}}\right)$ & - & - & 0 & 1 \\
\hline Crimea Federal District $\left(\right.$ CRIMEA $\left._{i}\right)$ & - & - & 0 & 1 \\
\hline
\end{tabular}

lation value ranging from low to moderate (Table 5) indicates a distortion of the results due to multicollinearity is unlikely. The results of the Ramsey test for erroneous specification of the regression model confirm the absence of missing variables in all models applied [Ramsey, 1969]. The results of the Breush-Pagan heteroskedasticity test indicate constant random error variance in all applied models [Breusch, Pagan, 1979].

All regression models are statistically significant. The control variables (Model 1) demonstrate a positive correlation between company size and their performance $(b=0.104, p<0.05)$ and a negative correlation between performance and company age $(b=-0.206, p<0.5)$. The industry variable is insignificant $(b=-0.043, p=0.697)$. In the Urals and Crimea Federal Districts, a negative correlation with companies' performance was discovered.

In Model 2, the SE entrepreneurial component's coefficient turned out to be positive and significant $(\mathrm{b}=$ $0.107, \mathrm{p}<0.05$ ), which allows one to reject the zero hypothesis and accept the alternative, in line with working hypothesis 1: during economic crises a positive correlation exists between the entrepreneurial component of SE and SME performance. This component remains significant and its coefficient remains positive even when a combined indicator with the strategic component is included in the model $(\mathrm{b}=0.269, \mathrm{p}<0.05$; model 3).
Hypothesis 2 was also tested in Model 2. The coefficient of the strategic component of SE turned out to be positive but statistically insignificant $(b=0.037, p=$ 0.494 ), that is, this hypothesis has not been confirmed. In Model 3, the coefficient of the combined strategic and entrepreneurial components of SE indicator turned out to be negative and insignificant $(b=-0.036, p=$ 0.233 ; model 3 ), accordingly, the "working" hypothesis 3 about the positive synergy between the entrepreneurial and strategic components in relation to SME performance was not confirmed in a statistically significant way. However, to analyze the matter more comprehensively, the combined indicators of the strategic component of SE and disaggregated parts of the entrepreneurial component (entrepreneurial mindset and innovation) were tested in the Models 4 and 5 , respectively, while the entrepreneurial component and disaggregated parts of the strategic component (competitive advantage and strategic management of resources) were tested in the Models 6 and 7, respectively. It was found that the combined application of the entrepreneurial component and competitive advantage negatively affected companies' performance $(\mathrm{b}=$ $-0.035, \mathrm{p}<0.1$; Model 4 ), and so did the combined use of the strategic component and innovation $(b=-0.052$, $\mathrm{p}<0.05$; Model 6 ). The remaining combined indicators turned out to be statistically insignificant. 
인

2

$\stackrel{\infty}{-}$

$-\begin{array}{rrr}0 & 1 \\ 0 & 0 \\ 0 & 0 \\ 0 & 0 \\ 0 & 0 \\ 0\end{array}$

$\approx$

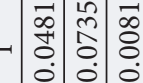

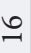

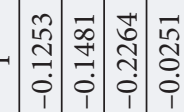

는

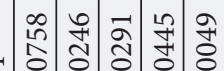

$-1$\begin{tabular}{lll|ll}
0 & 0 & 0 & 0 & 0 \\
0 & 0 & 0 & 0 \\
0 & 0 & 0 & 0 \\
0 & 1 & 1 & 1 & 1 \\
0 & 0 & 1
\end{tabular}

$\exists$

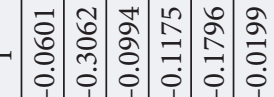

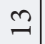

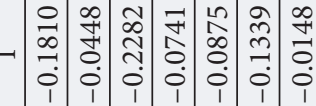

$\sim$

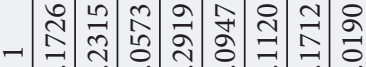

$=$

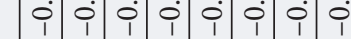

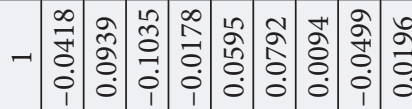

우

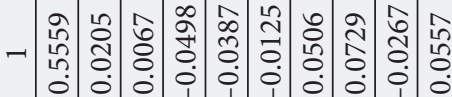

$a$

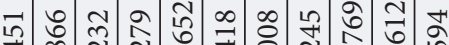

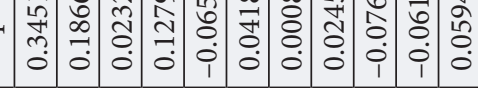

$\infty$

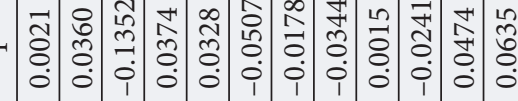

$\wedge$

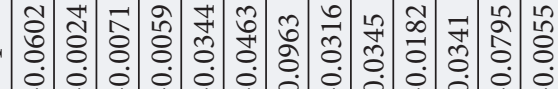

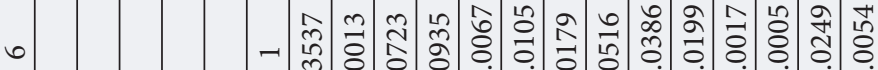

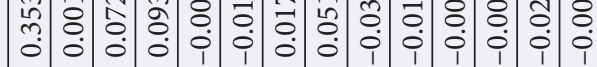

in

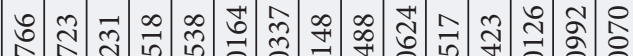

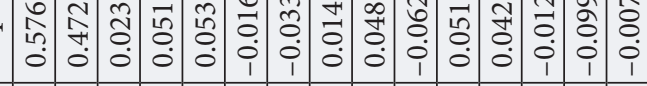

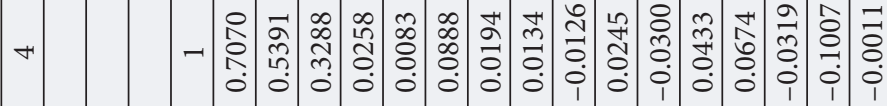

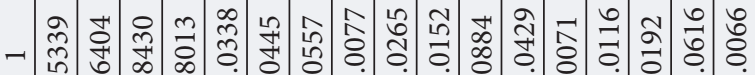

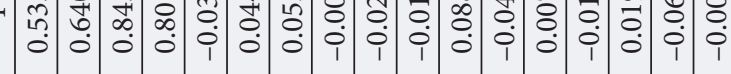

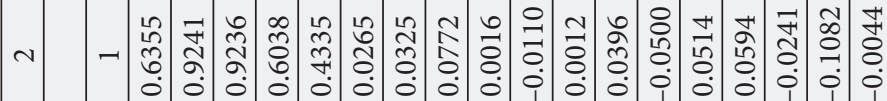

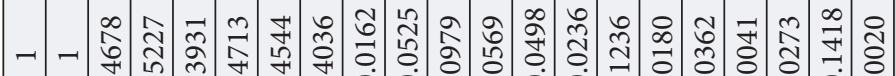

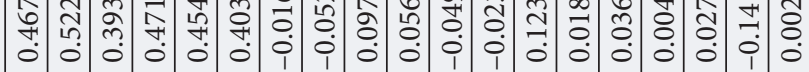

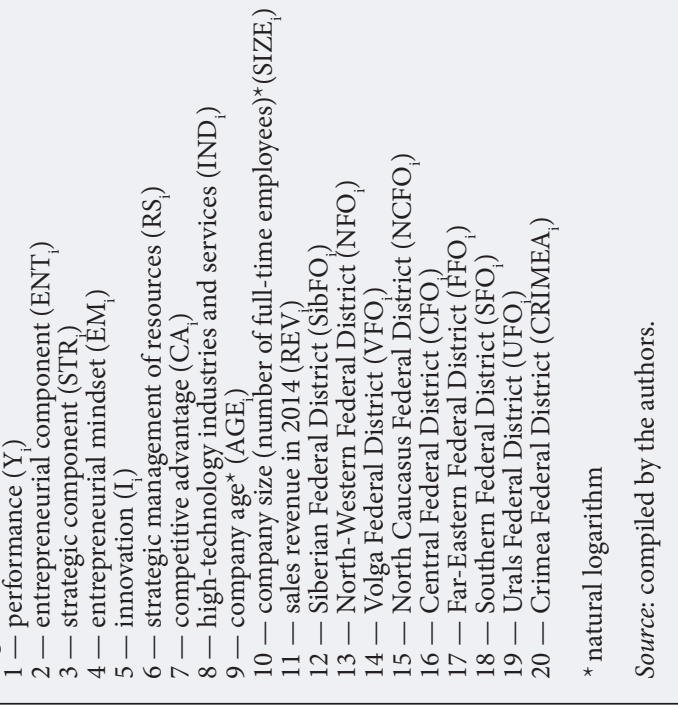

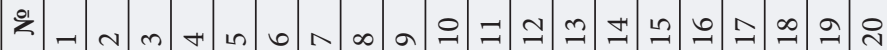


Table 5. Regression Analysis Results

\begin{tabular}{|c|c|c|c|c|c|c|c|}
\hline & Model 1 & Model 2 & Model 3 & Model 4 & Model 5 & Model 6 & Model 7 \\
\hline Entrepreneurial component $\left(\mathrm{ENT}_{\mathrm{i}}\right)$ & & $\begin{array}{l}0.107^{\star *} \\
(0.045)\end{array}$ & $\begin{array}{l}0.269^{* *} \\
(0.114) \\
\end{array}$ & $\begin{array}{l}0.311^{\star * *} \\
(0.117) \\
\end{array}$ & $\begin{array}{l}0.179^{* *} \\
(0.082) \\
\end{array}$ & & \\
\hline Strategic component $\left(\mathrm{STR}_{\mathrm{i}}\right)$ & & $\begin{array}{ll}0.037 \\
(0.054)\end{array}$ & $\begin{array}{ll}0.190^{*} \\
(0.113)\end{array}$ & & & $\begin{array}{l}0.303^{* * *} \\
(0.115)\end{array}$ & $\begin{array}{l}0.116 \\
(0.100)\end{array}$ \\
\hline $\begin{array}{l}\text { Entrepreneurial component } \times \text { Strategic } \\
\text { component }\left(\mathrm{ENT}_{i} \times \mathrm{STR}_{\mathrm{i}}\right)\end{array}$ & & & $\begin{array}{l}-0.036 \\
(0.023)\end{array}$ & & & & \\
\hline Competitive advantage $\left(\mathrm{CA}_{\mathrm{i}}\right)$ & & & & $\begin{array}{l}0.131 \\
(0.092)\end{array}$ & & & \\
\hline $\begin{array}{l}\text { Entrepreneurial component } x \text { Competitive } \\
\text { advantage }\left(\mathrm{ENT}_{\mathrm{i}} \times \mathrm{CA}_{\mathrm{i}}\right)\end{array}$ & & & & $\begin{array}{l}-0.035^{\star} \\
(0.021)\end{array}$ & & & \\
\hline Strategic management of resources $\left(\mathrm{RS}_{\mathrm{i}}\right)$ & & & & & $\begin{array}{l}0.150 \\
(0.095)\end{array}$ & & \\
\hline $\begin{array}{l}\text { Entrepreneurial component } x \text { Strategic } \\
\text { management of resources }\left(\mathrm{ENT}_{i} \times \mathrm{RS}_{i}\right)\end{array}$ & & & & & $\begin{array}{l}-0.023 \\
(0.019) \\
\end{array}$ & & \\
\hline Innovation $\left(I_{i}\right)$ & & & & & & $\begin{array}{l}0.291^{\star * *} \\
(0.103)\end{array}$ & \\
\hline Strategic component $\times$ Innovation $\left(\mathrm{STR}_{\mathrm{i}} \times \mathrm{I}_{\mathrm{i}}\right)$ & & & & & & $\begin{array}{l}-0.052^{\star *} \\
(0.022)\end{array}$ & \\
\hline Entrepreneurial mindset $\left(\mathrm{EM}_{\mathrm{i}}\right)$ & & & & & & & $\begin{array}{l}0.175 \\
(0.114)\end{array}$ \\
\hline $\begin{array}{l}\text { Strategic component } \times \text { Entrepreneurial mindset } \\
\left(\mathrm{STR}_{\mathrm{i}} \times \mathrm{EM}_{\mathrm{i}}\right)\end{array}$ & & & & & & & $\begin{array}{l}-0.017 \\
(0.023)\end{array}$ \\
\hline Company age $\left(\mathrm{AGE}_{\mathrm{i}}\right)$, natural logarithm & $\begin{array}{l}-0.206^{\star *} \\
(0.082) \\
\end{array}$ & $\begin{array}{l}-0.210^{* * *} \\
(0.081)\end{array}$ & $\begin{array}{l}-0.214^{\star * *} \\
(0.081)\end{array}$ & $\begin{array}{l}-0.210^{\star * *} \\
(0.081)\end{array}$ & $\begin{array}{l}-0.219^{* * *} \\
(0.081)\end{array}$ & $\begin{array}{l}-0.220^{* * *} \\
(0.081)\end{array}$ & $\begin{array}{l}-0.205^{\star *} \\
(0.081) \\
\end{array}$ \\
\hline $\begin{array}{l}\text { Company size (number of full-time employees) } \\
\text { (SIZE ), natural logarithm }\end{array}$ & $\begin{array}{l}0.104^{* *} \\
(0.053)\end{array}$ & $\begin{array}{l}0.088^{\star} \\
(0.053)\end{array}$ & $\begin{array}{l}0.086 \\
(0.053)\end{array}$ & $\begin{array}{l}0.085 \\
(0.053)\end{array}$ & $\begin{array}{l}0.083 \\
(0.053)\end{array}$ & $\begin{array}{l}0.090^{*} \\
(0.052)\end{array}$ & $\begin{array}{l}0.084 \\
(0.053)\end{array}$ \\
\hline Sales revenue in $2014\left(\mathrm{REV}_{\mathrm{i}}\right)$, natural logarithm & \begin{tabular}{|l|}
0.040 \\
$(0.031)$
\end{tabular} & \begin{tabular}{|l|}
0.047 \\
$(0.031)$
\end{tabular} & \begin{tabular}{|l|}
0.046 \\
$(0.031)$
\end{tabular} & \begin{tabular}{|l|}
0.046 \\
$(0.031)$
\end{tabular} & \begin{tabular}{|l|}
0.048 \\
$(0.031)$
\end{tabular} & \begin{tabular}{|l|}
0.045 \\
$(0.031)$
\end{tabular} & \begin{tabular}{|l|}
0.046 \\
$(0.031)$
\end{tabular} \\
\hline High-technology industries and services $\left(\mathrm{IND}_{\mathrm{i}}\right)$ & \begin{tabular}{|l}
-0.043 \\
$(0.111)$ \\
\end{tabular} & $\begin{array}{l}-0.046 \\
(0.110) \\
\end{array}$ & $\begin{array}{l}-0.039 \\
(0.110) \\
\end{array}$ & $\begin{array}{l}-0.040 \\
(0.110) \\
\end{array}$ & $\begin{array}{l}-0.046 \\
(0.110) \\
\end{array}$ & \begin{tabular}{|l}
-0.029 \\
$(0.110)$ \\
\end{tabular} & $\begin{array}{l}-0.042 \\
(0.110) \\
\end{array}$ \\
\hline Siberian Federal District $\left(\mathrm{SibFO}_{\mathrm{i}}\right)$ & $\begin{array}{l}-0.186 \\
(0.149) \\
\end{array}$ & $\begin{array}{l}-0.163 \\
(0.147) \\
\end{array}$ & $\begin{array}{l}-0.154 \\
(0.147) \\
\end{array}$ & $\begin{array}{l}-0.149 \\
(0.147) \\
\end{array}$ & $\begin{array}{l}-0.166 \\
(0.147) \\
\end{array}$ & \begin{tabular}{|l}
-0.147 \\
$(0.147)$ \\
\end{tabular} & $\begin{array}{l}-0.169 \\
(0.147) \\
\end{array}$ \\
\hline North-Western Federal District $\left(\mathrm{NFO}_{\mathrm{i}}\right)$ & \begin{tabular}{|l|}
-0.028 \\
$(0.171)$ \\
\end{tabular} & \begin{tabular}{|l|}
-0.014 \\
$(0.170)$ \\
\end{tabular} & $\begin{array}{l}-0.012 \\
(0.170) \\
\end{array}$ & $\begin{array}{l}-0.019 \\
(0.170) \\
\end{array}$ & $\begin{array}{l}-0.020 \\
(0.170) \\
\end{array}$ & \begin{tabular}{|l|}
-0.018 \\
$(0.170)$ \\
\end{tabular} & $\begin{array}{l}-0.010 \\
(0.170)\end{array}$ \\
\hline Volga Federal District $\left(\mathrm{VFO}_{\mathrm{i}}\right)$ & $\begin{array}{l}-0.085 \\
(0.145)\end{array}$ & $\begin{array}{l}-0.090 \\
(0.144)\end{array}$ & $\begin{array}{l}-0.088 \\
(0.144)\end{array}$ & $\begin{array}{l}-0.074 \\
(0.144)\end{array}$ & $\begin{array}{l}-0.095 \\
(0.144)\end{array}$ & $\begin{array}{l}-0.098 \\
(0.144)\end{array}$ & $\begin{array}{l}-0.089 \\
(0.144)\end{array}$ \\
\hline North Caucasus Federal District $\left(\mathrm{NCFO}_{\mathrm{i}}\right)$ & $\begin{array}{l}-0.510 \\
(0.416) \\
\end{array}$ & $\begin{array}{l}-0.422 \\
(0.413) \\
\end{array}$ & $\begin{array}{l}-0.408 \\
(0.412) \\
\end{array}$ & $\begin{array}{l}-0.406 \\
(0.412) \\
\end{array}$ & $\begin{array}{l}-0.421 \\
(0.412) \\
\end{array}$ & \begin{tabular}{|l|}
-0.393 \\
$(0.413)$ \\
\end{tabular} & \begin{tabular}{|l|}
-0.444 \\
$(0.412)$ \\
\end{tabular} \\
\hline Far-Eastern Federal District $\left(\mathrm{FFO}_{\mathrm{i}}\right)$ & $\begin{array}{l}-0.042 \\
(0.265) \\
\end{array}$ & $\begin{array}{l}-0.069 \\
(0.263) \\
\end{array}$ & $\begin{array}{l}-0.090 \\
(0.263) \\
\end{array}$ & $\begin{array}{l}-0.088 \\
(0.263) \\
\end{array}$ & $\begin{array}{l}-0.091 \\
(0.263) \\
\end{array}$ & \begin{tabular}{|l}
-0.084 \\
$(0.263)$ \\
\end{tabular} & $\begin{array}{l}-0.083 \\
(0.263) \\
\end{array}$ \\
\hline Southern Federal District $\left(\mathrm{SFO}_{\mathrm{i}}\right)$ & $\begin{array}{l}-0.030 \\
(0.232) \\
\end{array}$ & \begin{tabular}{|l}
0.001 \\
$(0.231)$ \\
\end{tabular} & $\begin{array}{l}-0.009 \\
(0.230) \\
\end{array}$ & \begin{tabular}{|l}
0.012 \\
$(0.230)$ \\
\end{tabular} & $\begin{array}{l}-0.013 \\
(0.231) \\
\end{array}$ & $\begin{array}{l}-0.029 \\
(0.230) \\
\end{array}$ & $\begin{array}{l}-0.001 \\
(0.231) \\
\end{array}$ \\
\hline Urals Federal District $\left(\mathrm{UFO}_{\mathrm{i}}\right)$ & \begin{tabular}{|l}
$-0.295^{\star}$ \\
$(0.171)$ \\
\end{tabular} & \begin{tabular}{|c}
-0.228 \\
$(0.171)$ \\
\end{tabular} & $\begin{array}{l}-0.211 \\
(0.171) \\
\end{array}$ & $\begin{array}{l}-0.206 \\
(0.171) \\
\end{array}$ & $\begin{array}{l}-0.233 \\
(0.171) \\
\end{array}$ & $\begin{array}{l}-0.219 \\
(0.170) \\
\end{array}$ & $\begin{array}{l}-0.223 \\
(0.171) \\
\end{array}$ \\
\hline Crimea Federal District $\left(\right.$ CRIMEA $\left._{\mathrm{i}}\right)$ & $\begin{array}{l}-2.221^{*} \\
(1.222)\end{array}$ & \begin{tabular}{|l}
$-2.154^{\star}$ \\
$(1.211)$
\end{tabular} & \begin{tabular}{|l|}
$-2.191^{\star}$ \\
$(1.210)$
\end{tabular} & \begin{tabular}{|l|}
$-2.184^{*}$ \\
$(1.210)$
\end{tabular} & \begin{tabular}{|l|}
$-2.175^{\star}$ \\
$(1.210)$
\end{tabular} & \begin{tabular}{|l}
$-2.217^{\star}$ \\
$(1.209)$
\end{tabular} & \begin{tabular}{|l|}
$-2.184^{*}$ \\
$(1.211)$
\end{tabular} \\
\hline Constant $\left(\mathrm{b}_{0}\right)$ & $\begin{array}{l}3.043^{* * *} \\
(0.324)\end{array}$ & $\begin{array}{l}2.352^{* * *} \\
(0.379)\end{array}$ & $\begin{array}{l}1.725^{\star * *} \\
(0.555)\end{array}$ & $\begin{array}{l}1.764^{* * *} \\
(0.565) \\
\end{array}$ & $\begin{array}{l}2.065^{\star * *} \\
(0.453)\end{array}$ & $\begin{array}{l}1.460^{* * *} \\
(0.550)\end{array}$ & $\begin{array}{l}2.085^{\star * *} \\
(0.533)\end{array}$ \\
\hline R-squared & 0.039 & 0.061 & 0.064 & 0.064 & 0.064 & 0.065 & 0.063 \\
\hline
\end{tabular}

Given that almost $30 \%$ of the sample firms are located in the Central Federal District (CFD), we decided to conduct additional analysis using the same regression models but excluding this district. The CFD is far ahead of other Russian districts in terms of most socioeconomic indicators (total gross regional product, the development of production and social infrastructure, etc.), and its economic structure is closer to that of post-industrial economies [Ministry of Economic Development, 2013]. The regression models' results are presented in Table 6. Among the control variables, company age ceases to have a significant correlation with company performance. For independent variables and their interactions, all previous results remained unchanged, but the combined indicator of the entrepreneurial and strategic components of SE became statistically significant, indicating a negative correlation between their simultaneous application and company performance outside the CFD. 
Table 6. Regression Analysis Results (with companies located in CFD excluded)

\begin{tabular}{|c|c|c|c|c|c|c|c|}
\hline & Model 8 & Model 9 & Model 10 & Model 11 & Model 12 & Model 13 & Model 14 \\
\hline Entrepreneurial component (ENTi) & & $\begin{array}{l}0.141^{* * *} \\
(0.051)\end{array}$ & $\begin{array}{l}0.381^{\star * *} \\
(0.130)\end{array}$ & $\begin{array}{l}0.472^{* * *} \\
(0.130)\end{array}$ & $\begin{array}{l}0.215^{\star *} \\
(0.094)\end{array}$ & & \\
\hline Strategic component (STRi) & & \begin{tabular}{|l|}
0.014 \\
$(0.061)$ \\
\end{tabular} & $\begin{array}{l}0.229^{*} \\
(0.123) \\
\end{array}$ & & & $\begin{array}{l}0.388^{\star * *} \\
(0.126) \\
\end{array}$ & $\begin{array}{l}0.119 \\
(0.109)\end{array}$ \\
\hline $\begin{array}{l}\text { Entrepreneurial component x } \\
\text { Strategic component (ENTi x STRi) }\end{array}$ & & & $\begin{array}{l}-0.053^{\star *} \\
(0.026)\end{array}$ & & & & \\
\hline Competitive advantage (CAi) & & & & $\begin{array}{l}0.214^{\star *} \\
(0.101)\end{array}$ & & & \\
\hline $\begin{array}{l}\text { Entrepreneurial component } \mathrm{x} \\
\text { Competitive advantage (ENTi x } \\
\text { CAi) }\end{array}$ & & & & $\begin{array}{l}-0.060^{* *} \\
(0.023)\end{array}$ & & & \\
\hline $\begin{array}{l}\text { Strategic management of resources } \\
\text { (RSi) }\end{array}$ & & & & & $\begin{array}{l}0.142 \\
(0.107)\end{array}$ & & \\
\hline $\begin{array}{l}\text { Entrepreneurial component } \mathrm{x} \\
\text { Strategic management of resources } \\
\text { (ENTix RSi) }\end{array}$ & & & & & $\begin{array}{l}-0.024 \\
(0.022)\end{array}$ & & \\
\hline Innovation (Ii) & & & & & & $\begin{array}{l}0.416^{\star * *} \\
(0.117)\end{array}$ & \\
\hline $\begin{array}{l}\text { Strategic component } x \text { Innovation } \\
\text { (STRi x Ii) }\end{array}$ & & & & & & $\begin{array}{l}-0.076^{* * *} \\
(0.025)\end{array}$ & \\
\hline Entrepreneurial mindset (EMi) & & & & & & & \begin{tabular}{|l|}
$0.233^{*}$ \\
$(0.128)$
\end{tabular} \\
\hline $\begin{array}{l}\text { Strategic component } x \\
\text { Entrepreneurial mindset (STRi } x \\
\text { EMi) }\end{array}$ & & & & & & & $\begin{array}{l}-0.023 \\
(0.025)\end{array}$ \\
\hline $\begin{array}{l}\text { Company age (AGEi), natural } \\
\text { logarithm }\end{array}$ & $\begin{array}{l}-0.130 \\
(0.095) \\
\end{array}$ & $\begin{array}{l}-0.145 \\
(0.094) \\
\end{array}$ & $\begin{array}{l}-0.147 \\
(0.094) \\
\end{array}$ & $\begin{array}{l}-0.146 \\
(0.093) \\
\end{array}$ & $\begin{array}{l}-0.154 \\
(0.094) \\
\end{array}$ & $\begin{array}{l}-0.148 \\
(0.094) \\
\end{array}$ & \begin{tabular}{|l|}
-0.141 \\
$(0.094)$ \\
\end{tabular} \\
\hline $\begin{array}{l}\text { Company size (number of full- } \\
\text { time employees) (SIZEi), natural } \\
\text { logarithm }\end{array}$ & $\begin{array}{l}0.133^{\star *} \\
(0.060) \\
\end{array}$ & $\begin{array}{l}0.116^{*} \\
(0.059)\end{array}$ & $\begin{array}{l}0.115^{*} \\
(0.059)\end{array}$ & $\begin{array}{l}0.110^{*} \\
(0.059)\end{array}$ & $\begin{array}{l}0.115^{*} \\
(0.059)\end{array}$ & $\begin{array}{l}0.120^{* *} \\
(0.059)\end{array}$ & $\begin{array}{l}0.113^{*} \\
(0.059)\end{array}$ \\
\hline $\begin{array}{l}\text { Sales revenues in } 2014 \text { (REVi), } \\
\text { natural logarithm }\end{array}$ & $\begin{array}{ll}0.018 \\
(0.035)\end{array}$ & $\begin{array}{ll}0.025 \\
(0.034)\end{array}$ & $\begin{array}{l}0.023 \\
(0.034) \\
\end{array}$ & $\begin{array}{l}0.024 \\
(0.034)\end{array}$ & $\begin{array}{ll}0.024 \\
(0.034)\end{array}$ & $\begin{array}{l}0.022 \\
(0.034)\end{array}$ & \begin{tabular}{|l|}
0.023 \\
$(0.034)$ \\
\end{tabular} \\
\hline $\begin{array}{l}\text { High-technology industries and } \\
\text { services (INDi) }\end{array}$ & $\begin{array}{l}-0.003 \\
(0.125)\end{array}$ & $\begin{array}{ll}-0.003 \\
(0.123)\end{array}$ & $\begin{array}{l}0.013 \\
(0.123)\end{array}$ & $\begin{array}{l}0.020 \\
(0.123)\end{array}$ & $\begin{array}{ll}0.002 \\
(0.123)\end{array}$ & $\begin{array}{l}0.032 \\
(0.123)\end{array}$ & \begin{tabular}{|l|}
0.007 \\
$(0.123)$
\end{tabular} \\
\hline $\begin{array}{l}\text { North-Western Federal District } \\
\text { (NFOi) }\end{array}$ & $\begin{array}{l}0.159 \\
(0.180)\end{array}$ & $\begin{array}{ll}0.151 \\
(0.177)\end{array}$ & $\begin{array}{l}0.141 \\
(0.177) \\
\end{array}$ & \begin{tabular}{|l|}
0.118 \\
$(0.177)$
\end{tabular} & $\begin{array}{l}0.151 \\
(0.177)\end{array}$ & $\begin{array}{l}0.122 \\
(0.177)\end{array}$ & $\begin{array}{l}0.166 \\
(0.177)\end{array}$ \\
\hline Volga Federal District (VFOi) & $\begin{array}{l}0.111 \\
(0.155)\end{array}$ & $\begin{array}{l}0.084 \\
(0.154)\end{array}$ & $\begin{array}{l}0.076 \\
(0.153)\end{array}$ & $\begin{array}{l}0.083 \\
(0.153)\end{array}$ & $\begin{array}{l}0.079 \\
(0.153)\end{array}$ & $\begin{array}{l}0.056 \\
(0.153)\end{array}$ & $\begin{array}{l}0.094 \\
(0.154)\end{array}$ \\
\hline $\begin{array}{l}\text { North Caucasus Federal District } \\
\text { (NCFOi) }\end{array}$ & $\begin{array}{l}-0.323 \\
(0.409)\end{array}$ & $\begin{array}{l}-0.245 \\
(0.403) \\
\end{array}$ & $\begin{array}{l}-0.239 \\
(0.402) \\
\end{array}$ & $\begin{array}{l}-0.241 \\
(0.401)\end{array}$ & $\begin{array}{l}-0.237 \\
(0.403) \\
\end{array}$ & $\begin{array}{l}-0.229 \\
(0.402)\end{array}$ & $\begin{array}{l}-0.265 \\
(0.403)\end{array}$ \\
\hline Far-Eastern Federal District (FFOi) & $\begin{array}{ll}0.155 \\
(0.266)\end{array}$ & $\begin{array}{ll}0.090 \\
(0.263)\end{array}$ & $\begin{array}{l}0.045 \\
(0.263)\end{array}$ & $\begin{array}{l}0.044 \\
(0.262)\end{array}$ & $\begin{array}{ll}0.072 \\
(0.264)\end{array}$ & $\begin{array}{l}0.041 \\
(0.263)\end{array}$ & $\begin{array}{l}0.080 \\
(0.263) \\
\end{array}$ \\
\hline Southern Federal District (SFOi) & $\begin{array}{l}0.172 \\
(0.235) \\
\end{array}$ & $\begin{array}{l}0.185 \\
(0.232) \\
\end{array}$ & $\begin{array}{l}0.160 \\
(0.232)\end{array}$ & $\begin{array}{l}0.175 \\
(0.231)\end{array}$ & $\begin{array}{l}0.170 \\
(0.232)\end{array}$ & $\begin{array}{l}0.126 \\
(0.231)\end{array}$ & $\begin{array}{l}0.190 \\
(0.233)\end{array}$ \\
\hline Urals Federal District (UFOi) & \begin{tabular}{|l|}
-0.098 \\
$(0.178)$ \\
\end{tabular} & \begin{tabular}{|l|}
-0.046 \\
$(0.176)$ \\
\end{tabular} & \begin{tabular}{|l|}
-0.033 \\
$(0.176)$ \\
\end{tabular} & $\begin{array}{l}-0.038 \\
(0.175) \\
\end{array}$ & \begin{tabular}{|l|}
-0.045 \\
$(0.176)$ \\
\end{tabular} & \begin{tabular}{|l|}
-0.053 \\
$(0.175)$ \\
\end{tabular} & \begin{tabular}{|l|}
-0.032 \\
$(0.176)$ \\
\end{tabular} \\
\hline Crimea Federal District (CRIMEAi) & $\begin{array}{l}-2.153^{\star} \\
(1.187)\end{array}$ & $\begin{array}{l}-2.101^{*} \\
(1.170)\end{array}$ & $\begin{array}{l}-2.175^{\star} \\
(1.167)\end{array}$ & $\begin{array}{l}-2.177^{\star} \\
(1.163)\end{array}$ & $\begin{array}{l}-2.126^{*} \\
(1.169)\end{array}$ & $\begin{array}{l}-2.235^{\star} \\
(1.165)\end{array}$ & $\begin{array}{l}-2.133^{*} \\
(1.169)\end{array}$ \\
\hline Constant (b0) & $\begin{array}{l}2.791^{\star * *} \\
(0.359)\end{array}$ & $\begin{array}{l}2.089^{* * *} \\
(0.415)\end{array}$ & \begin{tabular}{|l|}
$1.205^{\star *}$ \\
$(0.604)$
\end{tabular} & \begin{tabular}{|l|}
$1.049^{*}$ \\
$(0.608)$
\end{tabular} & $\begin{array}{l}1.745^{\star * *} \\
(0.504)\end{array}$ & $\begin{array}{l}0.816 \\
(0.598)\end{array}$ & $\begin{array}{l}1.738^{* * *} \\
(0.580)\end{array}$ \\
\hline R-squared & 0.039 & 0.070 & 0.079 & 0.085 & 0.074 & 0.081 & 0.074 \\
\hline
\end{tabular}

\section{Discussion of the Results}

An analysis of the relationship between the SE components (in particular, entrepreneurial and strategic ones) and Russian SMEs' performance during the economic crisis allowed us to make the following conclusions. A positive correlation exists between the entrepreneurial component of SE and the performance of Russian SMEs during economic crises. In such periods, entrepreneurs face serious threats that affect their financial situation and, ultimately, their very survival [Kunc, Bhandari, 2011; Pal et al., 2014]. However, deep economic shocks also create new opportunities [Beliaeva et al., 2018; Laskovaia et al., 2019; Pearce, Michael, 2006] and promote the application of new technologies and business models [Rae-Dupree, 2008]. Thus, Russian companies that experiment with new products, services, and business models tend to be less affected by crises. Studies based on data about devel- 
oped and emerging markets indicate that increased economic pressure often helps a firm make creative decisions that positively affect companies' financial performance [Beliaeva et al., 2018; Hausman, Johnston, 2014]. Players who rely on innovation also strengthen their market positions and leadership [Drickhamer, 2003; Guellec, Wunsch-Vincent, 2009; Pearce, Michael, 2006]. Thus, entrepreneurial decisions play a critical role in crisis situations and turn into key success factors for SMEs [Periz-Ortiz et al., 2008]. On the contrary, no statistically significant relationship was discovered between the strategic component of SE and companies' performance, nor between the industry-specific behavior of Russian SMEs during economic crises.

A negative correlation between the combined indicator of the entrepreneurial component and competitive advantage and the performance of Russian SMEs located outside the CFD indicates that companies have a limited resource base during economic crises. In such circumstances, companies located outside the CFD have to choose between entrepreneurial or strategic action since they cannot afford to carry out both at the same time [Ireland et al., 2003]. Including the CFD in the sample eliminates this effect, which serves as another confirmation of the unequal availability of resources in the central and other regions of the country. When this availability is further limited by a crisis, small companies focus on implementing only one SE component, since trying to combine entrepreneurial and strategic efforts can be fatal.

The theoretical originality of the study is in the proposed strategic concept of entrepreneurship in the framework of strategic management theory, with an emphasis placed upon individual SE components (entrepreneurial mindset, innovation, strategic management of resources, and competitive advantage), and in the analysis of small and medium enterprises' activities in the context of economic crises. In particular, we tried to demonstrate that the relationship between SE and SME performance during turbulent periods is notably different from stable economic conditions. For example, analyzing SMEs' strategic behavior in a sustainable context allows one to conclude that to achieve the best results, entrepreneurs should combine several strategic approaches (see, e.g., [Atuahene-Gima, Ko, 2001; Deutscher et al., 2016; Ho et al., 2016]). On the other hand, when resources are limited due to a crisis, combining several SE components results in decreased corporate performance indicators for SMEs.
Our study also makes a unique contribution regarding Russian SMEs during the economic crisis of 2014-2016 given the time when it was conducted and the nature of the sample. Studying post-crisis business strategies is fraught with the conclusions being biased and unreliable due to the management's cognitive distortions in the perception of companies' past behavior [Bao et al., 2011]. Furthermore, since the sample of domestic firms was random, the results obtained are applicable to all companies that meet the selection criteria.

The practical importance of this study for top managers, corporate decision makers, and those responsible for developing and implementing strategies lies in the identified approaches to company management that guarantee an organization's best performance during periods of economic crisis. It is important for SME managers to realize that combining specific SE components (which leads to improved performance under stable conditions) can have negative consequences during economic crises. In the latter case, they should focus on advancing entrepreneurial behavior, which normally involves innovation, willingness to take risks in developing new products and services, and the proactive search for and implementation of new business opportunities [Covin, Slevin, 1989; Soininen et al., 2012].

\section{Limitations of the Study and Future Directions for Research Areas}

These findings should be evaluated with certain provisos. First, the cross-sectional data used reflects shortterm company performance. A possible subject for further (longitudinal) research is the long-term impact of SE on SME performance. Second, the main dependent variable used in the study was a subjective indicator of companies' activities, namely their individual perception by managers. Despite the reliability of this approach, clarification of the obtained results requires further research. Third, we considered only the direct effects of specific SE components or their combinations. Authors of subsequent studies may choose to focus on other moderators of the correlation between SE and companies' performance. Replication studies using various samples (e.g., those comprising large firms and state-owned companies) may also be in order.

The study was supported with a grant provided by the Russian Science Foundation (project No. 19-18-00081).

\section{References}

Aldrich H., Auster E.R. (1986) Even dwarfs started small: Liabilities of age and size and their strategic implications. Research in Organizational Behavior, vol. 8, pp. 165-186.

Alonso-Almeida M.D.M., Bremser K., Llach J. (2015) Proactive and reactive strategies deployed by restaurants in times of crisis: Effects on capabilities, organization and competitive advantage. International Journal of Contemporary Hospitality Management, vol. 27, no 7, pp. 1641-1661.

Anderson B.S., Eshima Y. (2013) The influence of firm age and intangible resources on the relationship between entrepreneurial orientation and firm growth among Japanese SMEs. Journal of Business Venturing, vol. 28, no 3, pp. 413-429.

Antonioli D., Mazzanti M., Pini P. (2010) Productivity, innovation strategies and industrial relations in SMEs. Empirical evidence for a local production system in northern Italy. International Review of Applied Economics, vol. 24, no 4, pp. 453-482. 
Atuahene-Gima K., Ko A. (2001) An empirical investigation of the effect of market orientation and entrepreneurship orientation alignment on product innovation. Organization Science, vol. 12, no 1, pp. 54-74.

Audretsch D.B., Mahmood T. (1994) The rate of hazard confronting new firms and plants in US manufacturing. Review of Industrial Organization, vol. 9, no 1, pp. 41-56.

Awang A., Kassim A., Noor A.M., Shukor N., Shaari A.Z., Amran S., Khalid S.A. (2015) Strategic Entrepreneurship Model for Economic Transformation: Malaysian Evidence. Asian Social Science, vol. 11, no 7, pp. 19-34.

Bao Y., Olson B., Yuan W. (2011) Defensive and Expansion Responses to Environmental Shocks in China: Interpreting the 2008 Economic Crisis. Thunderbird International Business Review, vol. 53, no 2, pp. 225-245.

Barringer B. R., Bluedorn A. C. (1999) The relationship between corporate entrepreneurship and strategic management. Strategic Management Journal, vol. 20, no 5, pp. 421-444.

Baum J.A., Oliver C. (1996) Toward an institutional ecology of organizational founding. Academy of Management Journal, vol. 39, no 5, pp. 1378-1427.

Beliaeva T., Shirokova G., Wales W., Gafforova E. (2018) Benefiting from economic crisis? Strategic orientation effects, trade-offs, and configurations with resource availability on SME performance. International Entrepreneurship and Management Journal (first published online). DOI: 10.1007/s11365-018-0499-2.

Bjørnskov C., Foss N. (2013) How strategic entrepreneurship and the institutional context drive economic growth. Strategic Entrepreneurship Journal, vol. 7, no 1, pp. 50-69.

Boone C., Wezel F.C., van Witteloostuijn A. (2013) Joining the pack or going solo? A dynamic theory of new firm positioning. Journal of Business Venturing, vol. 28, no 4, pp. 511-527.

Breusch T.S., Pagan A.R. (1979) A Simple Test for Heteroskedasticity and Random Coefficient Variation. Econometrica, vol. 47, no 5, pp. 1287-1294.

Carlbäck M. (2012) Strategic entrepreneurship in the hotel industry: The role of chain affiliation. Scandinavian Journal of Hospitality and Tourism, vol. 12, no 4, pp. 349-372.

Carreira C., Silva F. (2010) No deep pockets: Some stylized empirical results on firms' financial constraints. Journal of Economic Surveys, vol. 24, no 4, pp. 731-753.

Chang S.J., van Witteloostuijn A., Eden L. (2010) From the editors: Common method variance in international business research. Journal of International Business Studies, vol. 41, no 2, pp. 178-184.

Chen M.J., Lin H.C., Michel J.G. (2010) Navigating in a hypercompetitive environment: The roles of action aggressiveness and TMT integration. Strategic Management Journal, vol. 31, no 13, pp. 1410-1430.

Chepurenko A. (2015) Teoria predprinimatel'stva: novye vyzovy I perspektivy [Entrepreneurship Theory: New Challenges and Future Prospects]. Foresight-Russia, vol. 9, no 2, pp. 44-57. DOI: 10.17323/1995-459x.2015.2.44.57 (in Russian).

Connaughton J.E., Madsen R.A. (2009) Regional implications of the 2001 recession. The Annals of Regional Science, vol. 43, no 2, pp. 491-507.

Covin J.G., Slevin D.P. (1989) Strategic management of small firms in hostile and benign environments. Strategic Management Journal, vol. 10, no 1 , pp. 75-87.

Danneels E. (2002) The dynamics of product innovation and firm competences. Strategic Management Journal, vol. 23, no 12, pp. $1095-1121$.

Darling J., Gabrielsson M., Seristö H. (2007) Enhancing contemporary entrepreneurship: A focus on management leadership. European Business Review, vol. 19, no 1, pp. 4-22.

Dawson J.F. (2014) Moderation in management research: What, why, when, and how. Journal of Business and Psychology, vol. 29, no 1, pp. 1-19.

De Oliveira Teixeira E., Werther W.B. (2013) Resilience: Continuous renewal of competitive advantages. Business Horizons, vol. 56, no 3 , pp. 333-342.

DeSimone L.D., Hatsopoulos G.N. (1995) How can big companies keep the entrepreneurial spirit alive? Harvard Business Review, vol. 73, no 6, pp. 183-189.

Dess G.G., Robinson R.B. (1984) Measuring organizational performance in the absence of objective measures: The case of the privately-held firm and conglomerate business unit. Strategic Management Journal, vol. 5, no 3, pp. 265-273.

Deutscher F., Zapkau F.B., Schwens C., Baum M., Kabst R. (2016) Strategic orientations and performance: A configurational perspective. Journal of Business Research, vol. 69, no 2, pp. 849-861.

Dhliwayo S. (2014) Entrepreneurship and Competitive Strategy: An Integrative Approach. Journal of Entrepreneurship, vol. 23, no 1, pp. 115-135.

Drickhamer D. (2003) Short-term gain, long-term pain. Industry Week, vol. 252, no 2, pp. 14.

Dutton J.E. (1986) The processing of crisis and non-crisis strategic issues. Journal of Management Studies, vol. 23, no 5, pp. 501-517.

Eisenhardt K.M., Martin J.A. (2000) Dynamic capabilities: What are they? Strategic Management Journal, vol. 21, no 10/11, pp. 1105-1121.

Gibson C.B., Birkinshaw J. (2004) The antecedents, consequences, and mediating role of organizational ambidexterity. Academy of Management Journal, vol. 47, no 2, pp. 209-226.

Grewal R., Tansuhaj P. (2001) Building organizational capabilities for managing economic crisis: The role of market orientation and strategic flexibility. Journal of Marketing, vol. 65, no 2, pp. 67-80.

Guellec D., Wunsch-Vincent S. (2009) Policy Responses to the Economic Crisis: Investing in Innovation for Long-Term Growth, Paris: OECD.

Harrison R.T., Cooper S.Y., Mason C.M. (2004) Entrepreneurial activity and the dynamics of technology-based cluster development: The case of Ottawa. Urban Studies, vol. 41, no 5-6, pp. 1045-1070.

Hausman A., Johnston W.J. (2014) The role of innovation in driving the economy: Lessons from the global financial crisis. Journal of Business Research, vol. 67, no 1, pp. 2720-2726.

He Z.L., Wong P.K. (2004) Exploration vs. exploitation: An empirical test of the ambidexterity hypothesis. Organization Science, vol. 15, no 4, pp. 481-494.

Hitt M.A., Beamish P.W., Jackson S.E., Mathieu J.E. (2007) Building theoretical and empirical bridges across levels: Multilevel research in management. Academy of Management Journal, vol. 50, no 6, pp. 1385-1399.

Hitt M.A., Ireland R.D., Camp S.M., Sexton D.L. (2001) Strategic entrepreneurship: Entrepreneurial strategies for wealth creation. Strategic Management Journal, vol. 22, no 6-7, pp. 479-491. 
Ho J., Plewa C., Lu V.N. (2016) Examining strategic orientation complementarity using multiple regression analysis and fuzzy set QCA. Journal of Business Research, vol. 69, no 6, pp. 2199-2205.

Hodorogel R.G. (2009) The economic crisis and its effects on SMEs. Theoretical and Applied Economics, vol. 5, no 5, pp. 79-88.

Ireland R.D., Hitt M. A., Sirmon D.G. (2003) A model of strategic entrepreneurship: The construct and its dimensions. Journal of Management, vol. 29, no 6, pp. 963-989.

Ireland R.D., Hitt M.A., Camp S.M., Sexton D.L. (2001) Integrating entrepreneurship and strategic management actions to create firm wealth. The Academy of Management Executive, vol. 15, no 1, pp. 49-63.

Ireland R.D., Webb J.W. (2007) Strategic entrepreneurship: Creating competitive advantage through streams of innovation. Business Horizons, vol. 50, no 1, pp. 49-59.

Ivvonen L., Shirokova G. (2016) Strategicheskoe predprinimatel'stvo: sushchnost'i osnovnye napravleniya issledovanii [Strategic entrepreneurship: essence and main research directions]. Vestnik of Saint Petersburg University. Management, no 4, pp. 21-53 (in Russian).

Jansen J.J., van den Bosch F.A., Volberda H.W. (2006) Exploratory innovation, exploitative innovation, and performance: Effects of organizational antecedents and environmental moderators. Management Science, vol. 52, no 11, pp. 1661-1674.

Kantur D. (2016) Strategic entrepreneurship: Mediating the entrepreneurial orientation-performance link. Management Decision, vol. 54, no 1, pp. 24-43.

Ketchen D.J., Ireland R.D., Snow C.C. (2007) Strategic entrepreneurship, collaborative innovation, and wealth creation. Strategic Entrepreneurship Journal, vol. 1, no 3-4, pp. 371-385.

Knight F. H. (1921) Risk, uncertainty and profit, New York: Hart, Schaffner and Marx.

Knudsen E.S., Lien L.B. (2015) Hire, Fire, or Train: Innovation and Human Capital Responses to Recessions. Strategic Entrepreneurship Journal, vol. 9, no 4, pp. 313-330.

Köksal H.M., Özgül E. (2007) The relationship between marketing strategies and performance in an economic crisis. Marketing Intelligence and Planning, vol. 25, no 4, pp. 326-342.

Kotha S. (2010) Spillovers, spillins, and strategic entrepreneurship: America's first commercial jet airplane and Boeing's ascendancy in commercial aviation. Strategic Entrepreneurship Journal, vol. 4, no 4, pp. 284-306.

Kunc M., Bhandari R. (2011) Strategic development processes during economic and financial crisis. Management Decision, vol. 49, no 8, pp. 1343-1353.

Kyrgidou L.P., Petridou E. (2011) The effect of competence exploration and competence exploitation on strategic entrepreneurship. Technology Analysis and Strategic Management, vol. 23, no 6, pp. 697-713.

Laskovaia A., Marino L., Shirokova G., Wales W. (2019) Expect the unexpected: Examining the shaping role of entrepreneurial orientation on causal and effectual decision-making logic during economic crisis. Entrepreneurship \& Regional Development, vol. 31, no 5-6, pp. 456-475. DOI: 10.1080/08985626.2018.1541593.

Latham S. (2009) Contrasting strategic response to economic recession in start-up versus established software firms. Journal of Small Business Management, vol. 47, no 2, pp. 180-201.

Levinthal D.A., March J.G. (1993) The myopia of learning. Strategic Management Journal, vol. 14, no S2, pp. 95-112.

Li H.H.J., Tan K.H., Hida A. (2011) Sustaining growth in electronic manufacturing sector: Lessons from Japanese mid-size EMS providers. International Journal of Production Research, vol. 49, no 18, pp. 5415-5430.

Ling Y., Kellermanns F.W. (2010) The effects of family firm specific sources of TMT diversity: The moderating role of information exchange frequency. Journal of Management Studies, vol. 47, no 2, pp. 322-344.

Löfgren A. (2014) International network management for the purpose of host market expansion: The mediating effect of co-innovation in the networks of SMEs. Journal of International Entrepreneurship, vol. 12, no 2, pp. 162-182.

Lubatkin M.H., Simsek Z., Ling Y., Veiga J.F. (2006) Ambidexterity and performance in small-to medium-sized firms: The pivotal role of top management team behavioral integration. Journal of Management, vol. 32, no 5, pp. 646-672.

Luke B., Kearins K., Verreynne M.L. (2011) Developing a conceptual framework of strategic entrepreneurship. International Journal of Entrepreneurial Behavior and Research, vol. 17, no 3, pp. 314-337.

Makadok R., Coff R.W. (2002) Dialogue: The Theory of Value and the Value of Theory: Breaking New Ground versus Reinventing the Wheel. Academy of Management Review, vol. 27, pp. 10-13.

March J.G. (1991) Exploration and exploitation in organizational learning. Organization Science, vol. 2, no 1, pp. 71-87.

Marcus A.A., Goodman R.S. (1991) Victims and shareholders: The dilemmas of presenting corporate policy during a crisis. Academy of Management Journal, vol. 34, no 2, pp. 281-305.

McGrath R.G. (2001) Exploratory learning, innovative capacity, and managerial oversight. Academy of Management Journal, vol. 44, no 1, pp. 118-131.

Mellahi K., Wilkinson A. (2004) Organizational failure: A critique of recent research and a proposed integrative framework. International Journal of Management Reviews, vol. 5, no 1, pp. 21-41.

Merrifield D.B. (1993) Intrapreneurial corporate renewal. Journal of Business Venturing, vol. 8, no 5, pp. 383-389.

Meuleman M., Amess K., Wright M., Scholes L. (2009) Agency, strategic entrepreneurship, and the performance of private equity-backed buyouts. Entrepreneurship Theory and Practice, vol. 33, no 1, pp. 213-239.

Meyer G.D., Heppard K.A. (2000) Entrepreneurship as strategy: Competing on the entrepreneurial edge, Thousand Oaks, CA: Sage Publications.

Mihalache O.R., Jansen J.J., van den Bosch F.A., Volberda H.W. (2014) Top management team shared leadership and organizational ambidexterity: A moderated mediation framework. Strategic Entrepreneurship Journal, vol. 8, no 2, pp. 128-148.

Miller D. (1983) The correlates of entrepreneurship in three types of firms. Management Science, vol. 29, no 7, pp. 770-791.

Miner A.S., Bassof P., Moorman C. (2001) Organizational improvisation and learning: A field study. Administrative Science Quarterly, vol. 46, no 2, pp. 304-337.

Ministry of Economic Development (2013) Prognoz dolgosrochnogo sotsial'no-ekonomicheskogo razvitiya Rossiiskoi Federatsii na period do 2030 goda, Moscow: RF Ministry of Economic Development (in Russian).

Mosakowski E. (2002) Overcoming resource disadvantages in entrepreneurial firms: When less is more. Strategic Entrepreneurship: Creating a New Mindset (eds. M.A. Hitt, R.D. Ireland, S.M. Camp, D. Sexton), Hoboken, NJ: Wiley-Blackwell, pp. 106-126.

Neter J., Wasserman W., Kutner M.H. (1990) Applied Linear Models, Regression, Analysis of Variance and Experimental Designs, Boston, MA: RD Irwin. 
O’Brien R.M. (2007) A caution regarding rules of thumb for variance inflation factors. Quality and Quantity, vol. 41, no 5, pp. 673-690.

Obeng B.A., Robson P., Haugh H. (2014) Strategic entrepreneurship and small firm growth in Ghana. International Small Business Journal, vol. 32, no 5, pp. 501-524.

Pal R., Torstensson H., Mattila H. (2014) Antecedents of organizational resilience in economic crises - an empirical study of Swedish textile and clothing SMEs. International Journal of Production Economics, vol. 147, part B, pp. 410-428.

Patzelt H., Shepherd D.A. (2009) Strategic entrepreneurship at universities: Academic entrepreneurs' assessment of policy programs. Entrepreneurship Theory and Practice, vol. 33, no 1, pp. 319-340.

Pearce J.A., Michael S.C. (2006) Strategies to prevent economic recessions from causing business failure. Business Horizons, vol. 49, no 3 , pp. 201-209.

Pearson C.M., Clair J.A. (1998) Reframing crisis management. Academy of Management Review, vol. 23, no 1, pp. 59-76.

Peris-Ortiz M., de Borja Trujillo-Ruiz F., Hervás-Oliver J.L. (2014) Business Start-ups and Innovation: The Effect of the 2008 Economic Crisis. Entrepreneurship, Innovation and Economic Crisis (eds. K. Rüdiger, M. Peris-Ortiz, A. Blanco-González), New York: Springer International Publishing, pp. 41-47.

Podsakoff P.M., Organ D.W. (1986) Self-reports in organizational research: Problems and prospects. Journal of Management, vol. 12, no 4, pp. 531-544.

Pollard D., Hotho S. (2006) Crises, scenarios and the strategic management process. Management Decision, vol. 44, no 6, pp. 721-736.

Rae-Dupree J. (2008) It's no time to forget about innovation. New York Times, 01.08.2008. Available at: https://www.nytimes.com/2008/11/02/ business/02unbox.html, accessed 15.02.2019.

Raisch S., Birkinshaw J., Probst G., Tushman M.L. (2009) Organizational ambidexterity: Balancing exploitation and exploration for sustained performance. Organization Science, vol. 20, no 4, pp. 685-695.

Ramsey J.B. (1969) Tests for Specification Errors in Classical Linear Least Squares Regression Analysis. Journal of the Royal Statistical Society Series B, vol. 31, no 2, pp. 350-371.

Reid G. (2007) The Foundations of Small Business Enterprise: An Entrepreneurial Analysis of Small Firm Inception and Growth, New York: Routledge.

Rhemtulla M., Brosseau-Liard P.É., Savalei V. (2012) When can categorical variables be treated as continuous? A comparison of robust continuous and categorical SEM estimation methods under suboptimal conditions. Psychological Methods, vol. 17, no 3, pp. $354-373$.

Schmitt A., Probst G., Tushman M.L. (2010) M@n@gement in times of economic crisis: Insights into organizational ambidexterity. M@n@gement, vol. 13, no 3,pp.128-150.

Schulze W.S., Lubatkin M.H., Dino R.N., Buchholtz A.K. (2001) Agency relationships in family firms: Theory and evidence. Organization Science, vol. 12, no 2, pp. 99-116.

Schumpeter J. (1942) Capitalism, socialism and democracy, New York: Harper \& Brothers.

Shane S., Venkataraman S. (2000) The promise of entrepreneurship as a field of research. Academy of Management Review, vol. 25, no 1, pp. 217-226.

Sheffi Y. (2007) Building a resilient organization. Bridge-Washington-National Academy of Engineering Bulletin, vol. 37, no 1, pp. 1-30.

Shirokova G., Vega G., Sokolova L. (2013) Performance of Russian SMEs: Exploration, Exploitation and Strategic Entrepreneurship. Critical Perspectives on International Business, vol. 9, no 1/2, pp. 173-203.

Siggelkow N., Levinthal D.A. (2003) Temporarily divide to conquer: Centralized, decentralized, and reintegrated organizational approaches to exploration and adaptation. Organization Science, vol. 14, no 6, pp. 650-669.

Sirén C.A., Kohtamäki M., Kuckertz A. (2012) Exploration and exploitation strategies, profit performance, and the mediating role of strategic learning: Escaping the exploitation trap. Strategic Entrepreneurship Journal, vol. 6, no 1, pp. 18-41.

Smolka K.M., Verheul I., Burmeister-Lamp K., Heugens P.P. (2018) Get It Together! Synergistic Effects of Causal and Effectual DecisionMaking Logics on Venture Performance. Entrepreneurship Theory and Practice, vol. 42, no 4, pp. 571-604.

Soininen J., Martikainen M., Puumalainen K., Kyläheiko K. (2012) Entrepreneurial orientation: Growth and profitability of Finnish smalland medium-sized enterprises. International Journal of Production Economics, vol. 140, no 2, pp. 614-621.

Stam W., Elfring T. (2008) Entrepreneurial orientation and new venture performance: The moderating role of intra-and extra- industry social capital. Academy of Management Journal, vol. 51, no 1, pp. 97-111.

Steffens P., Davidsson P., Fitzsimmons J. (2009) Performance configurations over time: Implications for growth-and profit-oriented strategies. Entrepreneurship Theory and Practice, vol. 33, no 1, pp. 125-148.

Sun Z. (2015) Technology innovation and entrepreneurial state: The development of China's high-speed rail industry. Technology Analysis and Strategic Management, vol. 27, no 6, pp. 646-659.

Tang Z., Hull C. (2012) An investigation of entrepreneurial orientation, perceived environmental hostility, and strategy application among Chinese SMEs. Journal of Small Business Management, vol. 50, no 1, pp. 132-158.

Uotila J., Maula M., Keil T., Zahra S.A. (2009) Exploration, exploitation, and financial performance: Analysis of S\&P 500 corporations. Strategic Management Journal, vol. 30, no 2, pp. 221-231.

Vargo J., Seville, E. (2011) Crisis strategic planning for SMEs: Finding the silver lining. International Journal of Production Research, vol. 49, no 18 , pp. 5619-5635.

Volberda H.W. (1996) Toward the flexible form: How to remain vital in hypercompetitive environments. Organization Science, vol. 7, no 4, pp. 359-374.

Wan W.P., Yiu D.W. (2009) From crisis to opportunity: Environmental jolt, corporate acquisitions, and firm performance. Strategic Management Journal, vol. 30, no 7, pp. 791-801.

Wiklund J., Shepherd D. (2005) Entrepreneurial orientation and small business performance: A configurational approach. Journal of Business Venturing, vol. 20, no 1, pp. 71-91.

Wooldridge J.M. (2003) Introductory Econometrics, Mason, OH: Thomson South-Western.

Yu F.L.T., Hu M.W. (2015) Strategic Entrepreneurship in Taiwan's Food and Catering Industries: The Case of $85^{\circ} \mathrm{C}$ Café Shop. Global Business Review, vol. 16, no 5, pp. 891-902.

Zahra S.A., Sapienza H.J., Davidsson P. (2006) Entrepreneurship and dynamic capabilities: A review, model and research agenda. Journal of Management Studies, vol. 43, no 4, pp. 917-955. 